\title{
Definitive Results of a Phase III Adjuvant Trial Comparing Six Cycles of FEC-100 to Four Cycles of AC in Women with Operable Node-negative Breast Cancer: The NSABP B-36 Trial (NRG Oncology)
}

\section{Charles E Geyer Jr ( $\nabla$ cgeyer@houstonmethodist.org )}

Houston Methodist Hospital https://orcid.org/0000-0003-0956-151X

Hanna Bandos

NSABP/NRG Oncology, and The University of Pittsburgh

\section{Priya Rastogi}

NSABP/NRG Oncology, and UMPC Hillman Cancer Center, and Magee Womens Hospital

\section{Samuel A Jacobs}

NSABP/NRG Oncology

\section{Andre Robidoux}

NSABP/NRG Oncology, and Centre Hospitalier de l'Universite de Montreal (CHUM)

\section{Louis Fehrenbacher}

NSABP/NRG Oncology, and Kaiser Permenente Northern California

\section{Patrick J Ward}

Oncology and Hematology Associates of Southwest Virginia

Jonathan Polikoff

NSABP/NRG Oncology, and Kaiser Permanente Southern California

\section{Adam M Brufsky}

NSABP/NRG Oncology, and Magee Womens Hospital

\section{Louise Provencher}

NSABP/NRG Oncology, and Centre des Maladies du Sein du CHU de Quebec - Universite Laval

\section{Alexander H.G. Paterson}

NSABP/NRG Oncology, and The Tom Baker Cancer Centre

\section{John T Hamm}

NSABP/NRG Oncology, and Norton Cancer Institute

Robert L Carolla

NSABP/NRG Oncology, and CCOP, Ozark Health Ventures LLC-Cancer Research for the Ozarks

\section{Luis Baez-Diaz}

NSABP/NRG Oncology, and Puerto Rico NCORP/UPR Comprehensive Cancer Center

Thomas B Julian

NSABP/NRG Oncology, and the Allegheny Health Network/Allegheny General Hospital

\section{Sandra Swain}

Georgetown Lombardi Comprehensive Cancer Center

\section{Terry Mamounas}


UF Health Cancer Center-Orlando Health

Norman Wolmark

University of Pittsburgh Cancer Institute: UPMC Hillman Cancer Center

\section{Research Article}

Keywords: Node-negative breast cancer, anthracyclines, duration of therapy

Posted Date: August 30th, 2021

DOI: https://doi.org/10.21203/rs.3.rs-841103/v1

License: 두 (i) This work is licensed under a Creative Commons Attribution 4.0 International License. Read Full License 


\section{Abstract}

PURPOSE: Results from adjuvant trials evaluating 6 cycles of epirubicin-based chemotherapy regimens suggested these programs may be more effective than 4 cycles of doxorubicin-based chemotherapy.

METHODS: NSABP B-36 was a phase III clinical trial originally designed as a $2 \times 2$ factorial study comparing 6 cycles of FEC-100 (5-FU, epirubicin, cyclophosphamide) to 4 cycles of conventional AC (Adriamycin/cyclophosphamide) with celecoxib or placebo. Shortly after activation, concerns regarding increased cardiovascular risks among selective COX-2 inhibitors resulted in a decision to remove the celecoxib/placebo from the trial. Women with histologically node-negative invasive breast cancer who had undergone primary surgery with a lumpectomy or total mastectomy were eligible. Primary endpoint was disease-free survival (DFS).

RESULTS: Between May 2004-July 2008, 2,722 patients were enrolled. Administration of FEC-100 did not result in improvement in DFS compared to $\mathrm{AC}(\mathrm{HR}=1.09 ; 95 \% \mathrm{Cl}$ 0.92-1.29, $\mathrm{p}$-value $=0.31)$. The effect of FEC-100 compared to AC on DFS was significantly different for receptor-positive ( $\mathrm{HR}=1.32,95 \% \mathrm{Cl}=1.05-1.66)$ compared to receptornegative patients $(\mathrm{HR}=0.86,95 \% \mathrm{Cl}=0.66-1.11)$ (treatment-by-receptor status interaction $\mathrm{p}$-value $=0.02)$. There was no statistically significant difference in the effect of treatment on overall survival (OS) with FEC-100 compared to AC (HR=1.06; 95\% Cl 0.84-1.35, p-value=0.61). Overall, Grade 3 and 4 adverse events were more frequent in the FEC100 group.

CONCLUSIONS: The results of B-36 do not support use of six-cycle anthracycline-based regimens in node-negative breast cancer. Prolongation of anthracycline-based therapy with FEC-100 does not improve DFS or OS, relative to AC for 4 cycles, and was associated with expected increases in toxicity. A statistically significant interaction between treatment and hormone receptor status favoring $\mathrm{AC}$ in hormone-receptor-positive breast cancers is consistent with the hypothesis that optimal duration of chemotherapy may be four cycles in these patients. Late cardiac events and deaths prior to recurrence or second cancer were infrequent on both arms, but slightly higher with FEC-100.

ClinicalTrials.gov: NCT00087178

\section{Introduction}

Prior to the development of taxanes as a component of adjuvant chemotherapy of early breast cancer, the National Surgical Adjuvant Breast and Bowel Project (NSABP) conducted a series of trials in patients with node-positive and node-negative breast cancer comparing four cycles of AC (doxorubicin and cyclophosphamide) to six cycles of CMF (cyclophosphamide, methotrexate, 5-FU), which established AC as an alternative standard regimen to CMF. ${ }^{1,2}$

A series of other studies attempting to improve outcomes relative to CMF were conducted in North America and France. The SWOG 8897 study $^{3}$ evaluated standard six cycle schedules of CAF (cyclophosphamide, doxorubicin, 5FU) compared to CMF in patients with high-risk, node-negative breast cancer. The regimen of CAF had similar disease-free survival (DFS) outcomes compared to CMF and only slightly better overall survival (OS) outcomes with greater toxicity. The NCIC MA5 trial ${ }^{4}$ compared CMF to six cycles of FEC-120 (5-FU, epirubicin, cyclophosphamide) in premenopausal women with node-positive breast cancer. There was an improvement in 10-year recurrence-free survival (RFS) with intensified FEC-120 with a trend toward improved survival, but at a cost of increased toxicity. 
The French Adjuvant Study Group (FASG) 01 trial $^{5}$ demonstrated improved outcomes with six cycles of FEC-50 compared to three cycles of FEC-50 in premenopausal women with node-positive breast cancer. The subsequent FASG 05 trial $^{6}$ showed that six cycles of FEC-100 was more effective than six cycles of FEC-50 in women with nodepositive breast cancer, without substantially increasing toxicity. These results suggested six cycles of anthracyclinebased chemotherapy might improve outcomes relative to the shorter-duration four-cycle AC regimen. A trial comparing four versus six cycles of $\mathrm{AC}$ was considered but was not developed due to concerns regarding increasing risks of cardiotoxicity with cumulative doses of $360 \mathrm{mg} / \mathrm{m} 2$ in women with node-negative breast cancer.

As an alternative, based on the activity and favorable toxicity profile of the six-cycle FEC-100 program, B-36 was designed to determine whether six cycles of FEC-100 would be superior to four cycles of AC for DFS, without substantially increased toxicity in the adjuvant setting in women with node-negative breast cancer. To better understand the relative impact of the 2 regimens on patients we incorporated a behavioral and health outcomes (BAHO) sub-study within the B-36 clinical trial, focusing on symptoms and quality of life. We also explored if posttreatment amenorrhea would influence outcomes and assessed the impact of the two regimens on cardiac function as measured by MUGA scan and self-report measures in a sub-study.

B-36 was originally designed as a 2x2 factorial study, which also randomly assigned patients to receive celecoxib or placebo for three years. Shortly after activation, concerns regarding increased cardiovascular risks among selective COX-2 inhibitors resulted in a decision to remove the celecoxib/placebo from the trial, so the original rationale for addressing the activity of celecoxib is not provided in this background but is available in the Background section of the protocol included in the Supplemental Appendix.

\section{Patients And Methods}

\section{Trial Design}

NSABP Protocol B-36 was a phase III trial that opened for accrual May 20, 2004 as a 2x2 factorial study to compare six cycles of 5 -fluorouracil $500 \mathrm{mg} / \mathrm{m} 2$, epirubicin $100 \mathrm{mg} / \mathrm{m} 2$ and cyclophosphamide $500 \mathrm{mg} / \mathrm{m} 2$ every 3 weeks (FEC-100) with four cycles of doxorubicin $60 \mathrm{mg} / \mathrm{m} 2$ and cyclophosphamide $600 \mathrm{mg} / \mathrm{m} 2$ every 3 weeks (AC) with celecoxib $400 \mathrm{mg}$ po BID or placebo administered for three years. Suspension of accrual occurred on December 17, 2004 due to uncertainty regarding cardiovascular risks of COX-2 inhibitors identified in ongoing chemoprevention trials after enrollment of 327 patients. The trial reopened for accrual on April 25, 2005 as a two-arm study of FEC100 vs AC following removal of celecoxib/placebo from the trial. The protocol was subsequently amended on November 22, 2005 to allow sequential administration of trastuzumab after chemotherapy for patients with HER2positive breast cancer at investigator's discretion. The study was closed to accrual on July 25,2008, after 2,722 women were enrolled.

Women treated with lumpectomy were required to receive breast radiotherapy after completion of their assigned chemotherapy. Administration of post-mastectomy chest wall radiotherapy was permitted at the discretion of the investigator; however regional nodal radiotherapy was prohibited. Women with estrogen receptor-positive or progesterone receptor-positive tumors received endocrine therapy for a minimum of five years after the completion of chemotherapy. The specific agents used for endocrine therapy were left to investigator discretion.

\section{Eligibility}


Enrollment required a pathologic diagnosis of invasive adenocarcinoma of the breast. Women with histologically node-negative invasive breast cancer who had undergone primary surgery with a lumpectomy or total mastectomy were eligible. Patients were required to have undergone axillary staging procedures with sentinel node biopsy or an axillary node dissection. Patients with hormone receptor-positive or -negative disease were eligible. Staging criteria for enrollment included T1-3 by clinical and pathological evaluation. Lymph nodes obtained from axillary staging procedures were required to be pNO according to pathological staging criteria of the AJCC Cancer Staging Manual, 6th edition. Other criteria included adequate hematological, hepatic, and renal function. Baseline left ventricular ejection fraction had to be equal to or greater than the lower limit of normal at the facility. Exclusion criteria included definitive evidence of metastatic disease, T4 tumors, bilateral breast cancer, or prior history of breast cancer (including DCIS). Patients with pure tubular or mucinous adenocarcinomas were not eligible

\section{Study Oversight}

The NSABP B-36 protocol was approved by the central institutional review board of the National Cancer Institute $(\mathrm{NCl})$ and by the human investigations committee or institutional review board at each participating site, each of which has approval for human subjects research from the Department of Health and Human Services. Written informed consent was obtained from all participants.

\section{Random Assignment and Stratification}

Patients were randomly assigned in a 1:1 ratio to receive either six cycles of FEC-100 or four cycles of AC and were stratified by hormone receptor status (ER or PgR positive, ER and PgR negative) and type of surgery (mastectomy, lumpectomy). Assignment to the two treatment groups was balanced with respect to the stratification factors. Random assignment was based on using a biased-coin minimization algorithm. ${ }^{7}$

\section{Endpoints}

The primary endpoint was disease-free survival (DFS), defined as time from random assignment to first local, regional, or distant recurrence, contralateral breast cancer, second primary cancer (other than squamous or basal cell carcinoma of the skin, melanoma in situ, carcinoma in situ of the cervix, or lobular carcinoma in situ of the breast), or death from any cause prior to recurrence or second primary. Secondary endpoints included OS, defined as time from random assignment to death from any cause, recurrence-free interval (RFI) defined as time from random assignment until first local, regional, or distant recurrence, and distant recurrence-free interval (DRFI) defined as time from random assignment until distant disease recurrence. Patients otherwise event-free were censored at the time of their last follow-up. Clinical assessment was required for determining patients' status for all endpoints except OS. Toxicities between the two regimens of chemotherapy FEC-100 and AC were also compared. Other secondary endpoints were components of the Behavioral and Health Outcomes (BAHO) sub-study, including quality of life and symptoms, development of post-chemotherapy amenorrhea, and a cardiac toxicity/cardiac function. ${ }^{8}$ Methods and outcomes of the BAHO analyses are reported in a companion manuscript.

\section{Sample size}

Following the early modification from the original $2 \times 2$ trial to a two-arm study, B-36 was designed to have $80 \%$ power to detect a $25 \%$ reduction in rate of DFS events with administration of FEC-100, using a 0.05 two-sided significance level. A total of 2,700 patients were to be enrolled to the study. Three formal interim analyses were planned with the final definitive analyses to be performed after the report of the 385th DFS event on both treatment arms combined. 


\section{Statistical methods}

Differences between the two treatment groups were evaluated by means of the log-rank test stratified for receptor status and type of surgery. The stratified Cox proportional-hazards model was used to estimate the hazard ratios and corresponding 95\% Cls. The proportional-hazards assumption for Cox's model was assessed by the method developed by Lin, Wei, and Ying. ${ }^{9}$ The Cox proportional-hazards model was used to estimate and control for the effects of additional prognostic variables and treatment-by-covariate interactions were investigated.

The Kaplan-Meier method was used to estimate rates of DFS and OS. Cumulative proportions of RFI and DRFI events were estimated using the competing risks analysis based on the cumulative incidence function. Death as a first event was considered as a competing event for RFI and DRFI. The analyses reported here are based on the intent-to-treat principle, and thus include all patients with follow-up, regardless of eligibility status and of the treatment received. Patients who experienced their first non-death event within 30 days from randomization were considered not to be at risk for the primary endpoint and were excluded. All P-values for the analyses were evaluated as significant at the two-sided 05 level. All statistical analyses were done in SAS, v9.4. The primary analyses were presented previously in an oral session at SABCS $2014 .{ }^{10}$ Analyses reported here include all data received as of May 31, 2016, which was the study closure date.

\section{Results}

\section{Patients}

Between May 2004 and July 2008, 2,722 patients were randomly assigned to the AC group (1,361) or the FEC-100 group $(1,361)$ (Fig. 1). Patient characteristics were well balanced between the two treatment groups (Table 1). Most of all randomized patients were $\geq 50$ years (60\%), had lumpectomy as definitive surgery (68\%), and had ER and/or PgR positive tumors (65\%). Trastuzumab was administered following completion of chemotherapy to $11 \%$ of patients. Approximately $60 \%$ of patients had a primary tumor of size $\leq 2 \mathrm{~cm}$ and $48 \%$ of tumors had either low or intermediate tumor grade. Patients randomized to celecoxib/placebo were included in the analyses. In total, 52 patients were identified as ineligible (25 on AC and 27 on FEC-100). Ninety patients (40 on AC and 50 on FEC-100) withdrew consent to be followed while on study. There were 20 patients (5 in AC and 15 in FEC-100) without followup and one patient from FEC-100 group who was considered as being not at risk for the primary endpoint were excluded from the analyses. The median follow-up time for 2,701 patients included in the efficacy analyses was 9.1 years. 
Table 1

Patient and tumor characteristics of patients enrolled in NSABP B-36

\begin{tabular}{|c|c|c|c|c|}
\hline \multirow[b]{2}{*}{ Characteristic } & \multicolumn{2}{|c|}{$\begin{array}{l}A C \\
(n=1,361)\end{array}$} & \multicolumn{2}{|c|}{$\begin{array}{l}\text { FEC-100 } \\
(n=1,361)\end{array}$} \\
\hline & $\mathbf{n}$ & $\%$ & $\mathbf{n}$ & $\%$ \\
\hline \multicolumn{5}{|l|}{ Age (years) } \\
\hline$<50$ & 548 & 40.3 & 550 & 40.4 \\
\hline$\geq 50$ & 813 & 59.7 & 811 & 59.6 \\
\hline \multicolumn{5}{|l|}{ Race } \\
\hline White & 1135 & 83.4 & 1162 & 85.4 \\
\hline Black & 141 & 10.4 & 116 & 8.5 \\
\hline Other & 57 & 4.2 & 60 & 4.4 \\
\hline Unknown & 28 & 2.1 & 23 & 1.7 \\
\hline \multicolumn{5}{|l|}{ Ethnic Origin } \\
\hline Hispanic & 83 & 6.1 & 97 & 7.1 \\
\hline Non-Hispanic & 1194 & 87.7 & 1185 & 87.1 \\
\hline Unknown & 84 & 6.2 & 79 & 5.8 \\
\hline \multicolumn{5}{|c|}{ Hormone receptor status } \\
\hline ER- and PgR- & 472 & 34.7 & 470 & 34.5 \\
\hline $\mathrm{ER}+$ and/or PgR+ & 889 & 65.3 & 891 & 65.5 \\
\hline \multicolumn{5}{|l|}{ Surgery Type } \\
\hline Lumpectomy & 919 & 67.5 & 924 & 67.9 \\
\hline Mastectomy & 442 & 32.5 & 437 & 32.1 \\
\hline \multicolumn{5}{|c|}{ Size of primary tumor } \\
\hline$\leq 2 \mathrm{~cm}$ & 812 & 59.7 & 833 & 61.2 \\
\hline $2.1-5 \mathrm{~cm}$ & 528 & 38.8 & 501 & 36.8 \\
\hline$>5 \mathrm{~cm}$ & 20 & 1.5 & 26 & 1.9 \\
\hline Unknown & 1 & 0.1 & 1 & 0.1 \\
\hline
\end{tabular}

$\mathrm{AC}=$ doxorubicin and cyclophosphamide; $\mathrm{ER}=$ estrogen receptor; FEC-100 = 5-fluorouracil, epirubicin and cyclophosphamide; PgR = progesterone receptor.

*Before the first event. 


\begin{tabular}{|lllll|}
\hline & AC & \multicolumn{3}{c|}{ FEC-100 } \\
& $(\mathbf{n = 1 , 3 6 1 )}$ & \multicolumn{3}{c|}{$(\mathbf{n = 1 , 3 6 1 )}$} \\
\hline Low & 150 & 11.0 & 136 & 10.0 \\
\hline Intermediate & 514 & 37.8 & 513 & 37.7 \\
\hline High & 691 & 50.8 & 704 & 51.7 \\
\hline Unknown & 6 & 0.4 & 8 & 0.6 \\
\hline Trastuzumab therapy* & & & & \\
\hline Yes & 160 & 11.8 & 151 & 11.1 \\
\hline No & 1195 & 87.8 & 1193 & 87.7 \\
\hline Unknown & 6 & 0.4 & 17 & 1.3 \\
\hline $\begin{array}{l}\text { AC = doxorubicin and cyclophosphamide; ER = estrogen receptor; FEC-100 } \\
\text { cyclophosphamide; PgR = progesterone receptor. }\end{array}$ & & & & \\
\hline *Before the first event. & & & & \\
\hline
\end{tabular}

\section{Treatment}

Among 2,701 patients eligible for the efficacy analyses, 7 (0.5\%) did not initiate AC and $13(1.0 \%)$ did not initiate FEC-100. Information on treatment initiation was not available from one AC patient and two FEC-100 patients. Overall, 1,315 (97\%) AC patients and 1,193 (88.7\%) FEC-100 patients completed planned protocol treatment. There were $16 \mathrm{AC}$ patients $(1.2 \%)$ and $47 \mathrm{FEC}-100(3.4 \%)$ patients who discontinued protocol therapy early due to adverse events (AEs). In addition, 11 patients ( $0.8 \%$ ) from the AC group and 75 (5.6\%) from the FEC-100 treatment group discontinued protocol therapy because of patient withdrawal or refusal. There were 21 patients who discontinued the protocol therapy due to other reasons (AC: 6 [0.4\%]; FEC-100: 15 [1.1\%]).

\section{Efficacy}

Since study entry, 521 (19.3\%) women had a DFS event (251 in the AC group and 270 in the FEC-100 group) (Table 2). Administration of FEC-100 did not result in improvement in DFS compared to AC ( $\mathrm{HR}=1.09 ; 95 \% \mathrm{Cl} 0.92-1.29$, $\mathrm{p}$-value $=0.31$ ). The type of first DFS events by treatment group are shown in Table 2. The nine-year DFS point estimates for AC and FEC-100 were $80.1 \%$ and $79.4 \%$, correspondingly (Fig. 2a). 
Table 2

Type of first events by treatment group: NSABP B-36

\begin{tabular}{|c|c|c|c|c|}
\hline \multirow[b]{2}{*}{ First event } & \multicolumn{2}{|c|}{$\begin{array}{l}\text { AC } \\
(n=1,355)\end{array}$} & \multicolumn{2}{|c|}{$\begin{array}{l}\text { FEC-100 } \\
(n=1,343)\end{array}$} \\
\hline & \# & $\%$ & $\#$ & $\%$ \\
\hline Distant recurrence & 76 & 5.6 & 70 & 5.2 \\
\hline Local-regional recurrence & 51 & 3.8 & 61 & 4.5 \\
\hline Contralateral breast cancer & 37 & 2.7 & 37 & 2.8 \\
\hline Second non-breast primary cancer & 62 & 4.6 & 68 & 5.1 \\
\hline Death & 25 & 1.8 & 34 & 2.5 \\
\hline Total first event & 251 & 18.5 & 270 & 20.1 \\
\hline Alive, event free & 1104 & 81.5 & 1073 & 79.9 \\
\hline
\end{tabular}

The effect of FEC-100 compared to AC on DFS was significantly different for receptor-positive $(\mathrm{HR}=1.32,95 \% \mathrm{Cl}=$ 1.05-1.66) compared to receptor-negative disease $(\mathrm{HR}=0.86,95 \% \mathrm{Cl}=0.66-1.11)$ (interaction between treatment and hormone receptor status; $p$-value $=0.02$ ) but was not different based on type of surgery. Additional analyses by histologic grade, tumor size, and age, also failed to demonstrate differences in DFS between FEC-100 and AC.

(Supplemental Fig. 1). Kaplan-Meyer curves by treatment and hormone receptor status are shown in Fig. 2b. The nine-year DFS point estimates for AC and FEC-100 were $85.0 \%$ and $80.8 \%$, respectively, in hormone receptor-positive disease and $70.9 \%$ and $76.5 \%$ in hormone receptor-negative disease. To further explore the effect of treatment according to hormone receptor status, sites of first events were tabulated by treatment and receptor status (Supplemental Table 1). Finally, the Cox model analysis demonstrated that histologic grade (low vs intermediate and high), tumor size ( $\leq 2 \mathrm{~cm}$ vs $>2 \mathrm{~cm}$ ), and race (White vs Black) were independently associated with DFS (Table 3). 
Table 3

Results of multivariable analyses of DFS: NSABP B-36

\begin{tabular}{|c|c|c|c|c|c|}
\hline Characteristic & & $\begin{array}{l}\text { No. of patients }{ }^{*} \\
(n=2,636)\end{array}$ & $\begin{array}{l}\text { No. (\%) } \\
\text { of DFS events }\end{array}$ & $\begin{array}{l}\text { Hazards Ratio } \\
(95 \% \mathrm{Cl})\end{array}$ & $P$-value \\
\hline Hormone receptor status ${ }^{\ddagger}$ & & & & & $0.02^{+}$ \\
\hline ER- and PgR- & AC & 455 & $122(26.8)$ & - & \\
\hline & FEC-100 & 454 & $104(22.9)$ & $0.87(0.67,1.13)$ & \\
\hline $\mathrm{ER}+$ and/or PgR+ & AC & 868 & $123(14.2)$ & - & \\
\hline & FEC-100 & 859 & $161(18.7)$ & $1.35(1.07,1.71)$ & \\
\hline Size of primary tumor & & & & & $<0.001$ \\
\hline$\leq 2 \mathrm{~cm}$ & & 1598 & $268(16.8)$ & - & \\
\hline$>2 \mathrm{~cm}$ & & 1040 & $242(23.3)$ & $1.39(1.17,1.66)$ & \\
\hline Tumor Grade & & & & & 0.01 \\
\hline Low & & 278 & $31(11.1)$ & - & \\
\hline Intermediate & & 1003 & $173(17.2)$ & $1.56(1.06,2.29)$ & \\
\hline High & & 1355 & $306(22.6)$ & $1.80(1.22,2.65)$ & \\
\hline Race & & & & & $<0.001$ \\
\hline White & & 2267 & $413(18.2)$ & - & \\
\hline Black & & 252 & $77(30.6)$ & $1.66(1.30,2.13)$ & \\
\hline Other & & 117 & $20(17.1)$ & $0.99(0.63,1.55)$ & \\
\hline
\end{tabular}

$A C=$ doxorubicin and cyclophosphamide; DFS = disease-free survival; ER = estrogen receptor; FEC-100 = 5fluorouracil, epirubicin and cyclophosphamide; $\mathrm{PgR}=$ progesterone receptor.

*62 patients were excluded due to either unknown race, histologic grade, or tumor size.

${ }^{\dagger} P$-value for the interaction between treatment and receptor status.

${ }^{\ddagger}$ For AC treatment group, $\mathrm{ER}+$ and/or PgR + compared to ER- and PgR-, $\mathrm{HR}=0.57,95 \% \mathrm{Cl}=0.43-0.75$; for FEC100 treatment group, $\mathrm{ER}+$ and/or $\mathrm{PgR}+$ compared to $\mathrm{ER}$ - and $\mathrm{PgR}-\mathrm{HR}=0.88,95 \% \mathrm{Cl}=0.67-1.14$.

Analysis of secondary endpoints demonstrated a total of 276 RFI events (140 in the AC group and 136 in the FEC100 group) and 201 distant recurrences (107 in the AC group and 94 in the FEC-100 group). There was no statistically significant difference in the effect of FEC-100 compared to AC on RFI ( $\mathrm{HR}=0.98 ; 95 \% \mathrm{Cl} 0.78-1.24$, $\mathrm{p}$ value $=0.88)$ and $\mathrm{DRFI}(\mathrm{HR}=0.89 ; 95 \% \mathrm{Cl} 0.68-1.18, \mathrm{p}$-value $=0.41)$. The cumulative incidence of RFI events through nine years was $10.7 \%$ in patients who received $A C$ and $10.4 \%$ in patients who received FEC- 100 . The cumulative incidence of distant recurrences through nine years was $8.3 \%$ in patients who received $A C$ and $7.2 \%$ in patients who received FEC-100. 
There were 132 and 139 cumulative deaths observed in the AC and FEC-100 treatment groups, correspondingly. There was no statistically significant difference in the effect of treatment on OS with FEC-100 compared to AC (HR $=1.06$; $95 \% \mathrm{Cl} 0.84-1.35$, p-value $=0.61$ ). The nine-year OS point estimates for AC and FEC-100 were $89.8 \%$ and $89.9 \%$, correspondingly (Fig. 2c). Analyses of these endpoints by treatment arm and hormone receptor status are provided in Supplemental Table 2. Interaction tests were not statistically significant for these endpoints.

\section{Adverse Events}

Among 2,701 patients eligible for the efficacy analyses, information on AEs was available for 2,682 (99\%) patients (1,349 AC; 1,333 FEC-100) (Table 4). Overall, Grade 3 and 4 AEs were more frequent in the FEC-100 treatment group. There were 51 patients (4\%) on the AC regimen and 98 (7\%) on the FEC-100 regimen with reported Grade 4 event as their highest. For 11 patients, a Grade $5 \mathrm{AE}$ was reported as the highest ( $3 \mathrm{AC}$; 8 FEC-100). There were seven cases of myeloid leukemia (5 AC; 2 FEC-100) and two cases of lymphoid leukemias (1 AC; 1 FEC-100) reported (among these nine patients, six were reported to have died while in follow-up). 
Table 4

Most common toxicities reported on NSABP B-36 - Greatest toxicity grade per patient

AC

$(n=1,349)$

\section{FEC-100}

$(n=1,333)$

\begin{tabular}{|c|c|c|c|c|c|c|c|c|c|c|}
\hline Term & $\begin{array}{l}\text { Grade } \\
<2\end{array}$ & $\begin{array}{l}\text { Grade } \\
2\end{array}$ & $\begin{array}{l}\text { Grade } \\
3\end{array}$ & $\begin{array}{l}\text { Grade } \\
4\end{array}$ & $\begin{array}{l}\text { Grade } \\
5\end{array}$ & $\begin{array}{l}\text { Grade } \\
<2\end{array}$ & $\begin{array}{l}\text { Grade } \\
2\end{array}$ & $\begin{array}{l}\text { Grade } \\
3\end{array}$ & $\begin{array}{l}\text { Grade } \\
4\end{array}$ & $\begin{array}{l}\text { Grade } \\
5\end{array}$ \\
\hline Overall* & $\begin{array}{l}964( \\
71.5 \\
\%)\end{array}$ & $\begin{array}{l}79( \\
5.9 \\
\%)\end{array}$ & $\begin{array}{l}252( \\
18.7 \\
\%)\end{array}$ & $\begin{array}{l}51( \\
3.8 \\
\%)\end{array}$ & $\begin{array}{l}3( \\
0.2 \\
\%)\end{array}$ & $\begin{array}{l}733( \\
55 \%)\end{array}$ & $\begin{array}{l}67(5 \\
\%)\end{array}$ & $\begin{array}{l}427( \\
32 \%)\end{array}$ & $\begin{array}{l}98( \\
7.4 \\
\%)\end{array}$ & $\begin{array}{l}8( \\
0.6 \\
\%)\end{array}$ \\
\hline $\begin{array}{l}\text { Febrile } \\
\text { neutropenia }\end{array}$ & $\begin{array}{l}1300( \\
96.4 \\
\%)\end{array}$ & $\begin{array}{l}0(0 \\
\%)\end{array}$ & $\begin{array}{l}45( \\
3.3 \\
\%)\end{array}$ & $\begin{array}{l}4( \\
0.3 \\
\%)\end{array}$ & $\begin{array}{l}0(0 \\
\%)\end{array}$ & $\begin{array}{l}1206( \\
90.5 \\
\%)\end{array}$ & $\begin{array}{l}0(0 \\
\%)\end{array}$ & $\begin{array}{l}113( \\
8.5 \\
\%)\end{array}$ & $\begin{array}{l}13(1 \\
\%)\end{array}$ & $\begin{array}{l}1( \\
0.1 \\
\%)\end{array}$ \\
\hline Fatigue & $\begin{array}{l}1231( \\
91.3 \\
\%)\end{array}$ & $\begin{array}{l}70( \\
5.2 \\
\%)\end{array}$ & $\begin{array}{l}48( \\
3.6 \\
\%)\end{array}$ & $\begin{array}{l}0(0 \\
\%)\end{array}$ & $\begin{array}{l}0(0 \\
\%)\end{array}$ & $\begin{array}{l}1170( \\
87.8 \\
\%)\end{array}$ & $\begin{array}{l}51( \\
3.8 \\
\%)\end{array}$ & $\begin{array}{l}112( \\
8.4 \\
\%)\end{array}$ & $\begin{array}{l}0(0 \\
\%)\end{array}$ & $\begin{array}{l}0(0 \\
\%)\end{array}$ \\
\hline Vomiting & $\begin{array}{l}1287( \\
95.4 \\
\%)\end{array}$ & $\begin{array}{l}21( \\
1.6 \\
\%)\end{array}$ & $\begin{array}{l}41(3 \\
\%)\end{array}$ & $\begin{array}{l}0(0 \\
\%)\end{array}$ & $\begin{array}{l}0(0 \\
\%)\end{array}$ & $\begin{array}{l}1236( \\
92.7 \\
\%)\end{array}$ & $\begin{array}{l}30( \\
2.3 \\
\%)\end{array}$ & $\begin{array}{l}67(5 \\
\%)\end{array}$ & $\begin{array}{l}0(0 \\
\%)\end{array}$ & $\begin{array}{l}0(0 \\
\%)\end{array}$ \\
\hline $\begin{array}{l}\text { Neutrophil count } \\
\text { decreased }\end{array}$ & $\begin{array}{l}1285( \\
95.3 \\
\%)\end{array}$ & $\begin{array}{l}14(1 \\
\%)\end{array}$ & $\begin{array}{l}21( \\
1.6 \\
\%)\end{array}$ & $\begin{array}{l}29( \\
2.1 \\
\%)\end{array}$ & $\begin{array}{l}0(0 \\
\%)\end{array}$ & $\begin{array}{l}1255( \\
94.1 \\
\%)\end{array}$ & $\begin{array}{l}20( \\
1.5 \\
\%)\end{array}$ & $\begin{array}{l}24( \\
1.8 \\
\%)\end{array}$ & $\begin{array}{l}34( \\
2.6 \\
\%)\end{array}$ & $\begin{array}{l}0(0 \\
\%)\end{array}$ \\
\hline Nausea & $\begin{array}{l}1256( \\
93.1 \\
\%)\end{array}$ & $\begin{array}{l}58( \\
4.3 \\
\%)\end{array}$ & $\begin{array}{l}35( \\
2.6 \\
\%)\end{array}$ & $\begin{array}{l}0(0 \\
\%)\end{array}$ & $\begin{array}{l}0(0 \\
\%)\end{array}$ & $\begin{array}{l}1213( \\
91.0 \\
\%)\end{array}$ & $\begin{array}{l}61( \\
4.6 \\
\%)\end{array}$ & $\begin{array}{l}59( \\
4.4 \\
\%)\end{array}$ & $\begin{array}{l}0(0 \\
\%)\end{array}$ & $\begin{array}{l}0(0 \\
\%)\end{array}$ \\
\hline $\begin{array}{l}\text { Platelet count } \\
\text { decreased }\end{array}$ & $\begin{array}{l}1338( \\
99.2 \\
\%)\end{array}$ & $\begin{array}{l}1( \\
0.1 \\
\%)\end{array}$ & $\begin{array}{l}4( \\
0.3 \\
\%)\end{array}$ & $\begin{array}{l}6( \\
0.4 \\
\%)\end{array}$ & $\begin{array}{l}0(0 \\
\%)\end{array}$ & $\begin{array}{l}1270( \\
95.3 \\
\%)\end{array}$ & $\begin{array}{l}3( \\
0.2 \\
\%)\end{array}$ & $\begin{array}{l}30( \\
2.3 \\
\%)\end{array}$ & $\begin{array}{l}30( \\
2.3 \\
\%)\end{array}$ & $\begin{array}{l}0(0 \\
\%)\end{array}$ \\
\hline $\begin{array}{l}\text { Infections and } \\
\text { infestations - } \\
\text { Other, specify }\end{array}$ & $\begin{array}{l}1314( \\
97.4 \\
\%)\end{array}$ & $\begin{array}{l}9( \\
0.7 \\
\%)\end{array}$ & $\begin{array}{l}26( \\
1.9 \\
\%)\end{array}$ & $\begin{array}{l}0(0 \\
\%)\end{array}$ & $\begin{array}{l}0(0 \\
\%)\end{array}$ & $\begin{array}{l}1276( \\
95.7 \\
\%)\end{array}$ & $\begin{array}{l}14( \\
1.1 \\
\%)\end{array}$ & $\begin{array}{l}41( \\
3.1 \\
\%)\end{array}$ & $\begin{array}{l}2( \\
0.2 \\
\%)\end{array}$ & $\begin{array}{l}0(0 \\
\%)\end{array}$ \\
\hline $\begin{array}{l}\text { Thromboembolic } \\
\text { event }\end{array}$ & $\begin{array}{l}1326( \\
98.3 \\
\%)\end{array}$ & $\begin{array}{l}0(0 \\
\%)\end{array}$ & $\begin{array}{l}19( \\
1.4 \\
\%)\end{array}$ & $\begin{array}{l}4( \\
0.3 \\
\%)\end{array}$ & $\begin{array}{l}0(0 \\
\%)\end{array}$ & $\begin{array}{l}1288( \\
96.6 \\
\%)\end{array}$ & $\begin{array}{l}0(0 \\
\%)\end{array}$ & $\begin{array}{l}38( \\
2.9 \\
\%)\end{array}$ & $\begin{array}{l}7( \\
0.5 \\
\%)\end{array}$ & $\begin{array}{l}0(0 \\
\%)\end{array}$ \\
\hline Anemia & $\begin{array}{l}1315( \\
97.5 \\
\%)\end{array}$ & $\begin{array}{l}12( \\
0.9 \\
\%)\end{array}$ & $\begin{array}{l}21( \\
1.6 \\
\%)\end{array}$ & $\begin{array}{l}1( \\
0.1 \\
\%)\end{array}$ & $\begin{array}{l}0(0 \\
\%)\end{array}$ & $\begin{array}{l}1261( \\
94.6 \\
\%)\end{array}$ & $\begin{array}{l}28( \\
2.1 \\
\%)\end{array}$ & $\begin{array}{l}37( \\
2.8 \\
\%)\end{array}$ & $\begin{array}{l}7( \\
0.5 \\
\%)\end{array}$ & $\begin{array}{l}0(0 \\
\%)\end{array}$ \\
\hline
\end{tabular}

$\mathrm{AC}=$ doxorubicin and cyclophosphamide; FEC-100=5-fluorouracil, epirubicin and cyclophosphamide; NOS=Not Otherwise Specified.

Adverse events occurring in $\geq 5 \%$ of patients and all Grade $3-5$ events occurring in $\geq 1 \%$ of patients are presented. Per protocol, adverse events were to be assessed and reported at the end of each chemotherapy cycle; in addition, unexpected with hospitalization Grade 3 adverse events, unexpected Grade 4 and all Grade 5 that occur $>30$ days after the last dose of study therapy with attribution of possible-, probable-, or definite-tostudy therapy required reporting.

*There were three Grade 5 adverse events in the AC treatment group (Sudden death NOS, Enterocolitis infectious, Leukemia secondary to oncology chemotherapy) and eight in the FEC-100 treatment group (two cases of Sudden death NOS, Leukemia secondary to oncology, Death NOS, Febrile neutropenia, Left ventricular systolic dysfunction (LVSD), Endocarditis infective, and Heart failure). 


\begin{tabular}{|c|c|c|c|c|c|c|c|c|c|c|}
\hline \multirow[b]{2}{*}{ Mucositis oral } & \multicolumn{5}{|c|}{$\begin{array}{l}\text { AC } \\
(n=1,349)\end{array}$} & \multicolumn{5}{|c|}{$\begin{array}{l}\text { FEC-100 } \\
(n=1,333)\end{array}$} \\
\hline & $\begin{array}{l}1309( \\
97 \%)\end{array}$ & $\begin{array}{l}31( \\
2.3 \\
\%)\end{array}$ & $\begin{array}{l}9( \\
0.7 \\
\%)\end{array}$ & $\begin{array}{l}0(0 \\
\%)\end{array}$ & $\begin{array}{l}0(0 \\
\%)\end{array}$ & $\begin{array}{l}1253( \\
94 \%)\end{array}$ & $\begin{array}{l}36( \\
2.7 \\
\%)\end{array}$ & $\begin{array}{l}43( \\
3.2 \\
\%)\end{array}$ & $\begin{array}{l}1( \\
0.1 \\
\%)\end{array}$ & $\begin{array}{l}0(0 \\
\%)\end{array}$ \\
\hline Dehydration & $\begin{array}{l}1333( \\
98.8 \\
\%)\end{array}$ & $\begin{array}{l}5( \\
0.4 \\
\%)\end{array}$ & $\begin{array}{l}11( \\
0.8 \\
\%)\end{array}$ & $\begin{array}{l}0(0 \\
\%)\end{array}$ & $\begin{array}{l}0(0 \\
\%)\end{array}$ & $\begin{array}{l}1288( \\
96.6 \\
\%)\end{array}$ & $\begin{array}{l}12( \\
0.9 \\
\%)\end{array}$ & $\begin{array}{l}33( \\
2.5 \\
\%)\end{array}$ & $\begin{array}{l}0(0 \\
\%)\end{array}$ & $\begin{array}{l}0(0 \\
\%)\end{array}$ \\
\hline Diarrhea & $\begin{array}{l}1327( \\
98.4 \\
\%)\end{array}$ & $\begin{array}{l}11( \\
0.8 \\
\%)\end{array}$ & $\begin{array}{l}11( \\
0.8 \\
\%)\end{array}$ & $\begin{array}{l}0(0 \\
\%)\end{array}$ & $\begin{array}{l}0(0 \\
\%)\end{array}$ & $\begin{array}{l}1289( \\
96.7 \\
\%)\end{array}$ & $\begin{array}{l}14( \\
1.1 \\
\%)\end{array}$ & $\begin{array}{l}30( \\
2.3 \\
\%)\end{array}$ & $\begin{array}{l}0(0 \\
\%)\end{array}$ & $\begin{array}{l}0(0 \\
\%)\end{array}$ \\
\hline Hyperglycemia & $\begin{array}{l}1332( \\
98.7 \\
\%)\end{array}$ & $\begin{array}{l}3( \\
0.2 \\
\%)\end{array}$ & $\begin{array}{l}13(1 \\
\%)\end{array}$ & $\begin{array}{l}1( \\
0.1 \\
\%)\end{array}$ & $\begin{array}{l}0(0 \\
\%)\end{array}$ & $\begin{array}{l}1307( \\
98 \%)\end{array}$ & $\begin{array}{l}2( \\
0.2 \\
\%)\end{array}$ & $\begin{array}{l}23( \\
1.7 \\
\%)\end{array}$ & $\begin{array}{l}1( \\
0.1 \\
\%)\end{array}$ & $\begin{array}{l}0(0 \\
\%)\end{array}$ \\
\hline Syncope & $\begin{array}{l}1341( \\
99.4 \\
\%)\end{array}$ & $\begin{array}{l}0(0 \\
\%)\end{array}$ & $\begin{array}{l}8( \\
0.6 \\
\%)\end{array}$ & $\begin{array}{l}0(0 \\
\%)\end{array}$ & $\begin{array}{l}0(0 \\
\%)\end{array}$ & $\begin{array}{l}1309( \\
98.2 \\
\%)\end{array}$ & $\begin{array}{l}0(0 \\
\%)\end{array}$ & $\begin{array}{l}24( \\
1.8 \\
\%)\end{array}$ & $\begin{array}{l}0(0 \\
\%)\end{array}$ & $\begin{array}{l}0(0 \\
\%)\end{array}$ \\
\hline Headache & $\begin{array}{l}1324( \\
98.1 \\
\%)\end{array}$ & $\begin{array}{l}14(1 \\
\%)\end{array}$ & $\begin{array}{l}11( \\
0.8 \\
\%)\end{array}$ & $\begin{array}{l}0(0 \\
\%)\end{array}$ & $\begin{array}{l}0(0 \\
\%)\end{array}$ & $\begin{array}{l}1302( \\
97.7 \\
\%)\end{array}$ & $\begin{array}{l}15( \\
1.1 \\
\%)\end{array}$ & $\begin{array}{l}16( \\
1.2 \\
\%)\end{array}$ & $\begin{array}{l}0(0 \\
\%)\end{array}$ & $\begin{array}{l}0(0 \\
\%)\end{array}$ \\
\hline Hypokalemia & $\begin{array}{l}1337( \\
99.1 \\
\%)\end{array}$ & $\begin{array}{l}0(0 \\
\%)\end{array}$ & $\begin{array}{l}12( \\
0.9 \\
\%)\end{array}$ & $\begin{array}{l}0(0 \\
\%)\end{array}$ & $\begin{array}{l}0(0 \\
\%)\end{array}$ & $\begin{array}{l}1319( \\
98.9 \\
\%)\end{array}$ & $\begin{array}{l}0(0 \\
\%)\end{array}$ & $\begin{array}{l}14( \\
1.1 \\
\%)\end{array}$ & $\begin{array}{l}0(0 \\
\%)\end{array}$ & $\begin{array}{l}0(0 \\
\%)\end{array}$ \\
\hline \multicolumn{11}{|c|}{$\begin{array}{l}\text { Adverse events occurring in } \geq 5 \% \text { of patients and all Grade } 3-5 \text { events occurring in } \geq 1 \% \text { of patients are } \\
\text { presented. Per protocol, adverse events were to be assessed and reported at the end of each chemotherapy } \\
\text { cycle; in addition, unexpected with hospitalization Grade } 3 \text { adverse events, unexpected Grade } 4 \text { and all Grade } 5 \\
\text { that occur }>30 \text { days after the last dose of study therapy with attribution of possible-, probable-, or definite-to- } \\
\text { study therapy required reporting. }\end{array}$} \\
\hline \multicolumn{11}{|c|}{$\begin{array}{l}\text { *There were three Grade } 5 \text { adverse events in the AC treatment group (Sudden death NOS, Enterocolitis } \\
\text { infectious, Leukemia secondary to oncology chemotherapy) and eight in the FEC-100 treatment group (two } \\
\text { cases of Sudden death NOS, Leukemia secondary to oncology, Death NOS, Febrile neutropenia, Left ventricular } \\
\text { systolic dysfunction (LVSD), Endocarditis infective, and Heart failure). }\end{array}$} \\
\hline
\end{tabular}

Late cardiac AEs reported after completion of the protocol treatment and before cancer recurrence, which were considered possibly related to chemotherapy per investigator, were recorded for 30 patients (8 AC; 22 FEC-100). Among them, the initiation of trastuzumab before the late cardiac event had been reported for nine patients ( 3 AC; 6 FEC-100) (Supplemental Table 3).

Deaths prior to recurrence or second primary tumors occurred in 25/1,355 (1.8\%) patients in the AC arm and $34 / 1343(2.5 \%)$ in the FEC-100 arm. Etiologies of the deaths reported by investigators are shown in Supplemental

Table 4.

Discussion 
The Consensus Conference on Adjuvant Therapy of Breast Cancer held in November of 2000 had stressed the need for clinical trials to specifically address the issue of cycle duration. ${ }^{11}$ NSABP B-36 was designed to determine whether six cycles of an anthracycline-based chemotherapy regimen were better than four cycles of conventional AC in a node-negative patient population. Prolongation of anthracycline-based therapy with FEC-100 for six cycles did not improve DFS, RFI, DRFI, or OS, relative to AC for four cycles, and was associated with expected increases in toxicity, particularly febrile neutropenia and mucositis. Higher histologic grade, larger tumor size and Black vs White race were independently associated with increased risk for DFS events. Symptomatic CHF was fortunately rare in both groups with nine years of follow-up. Rates of treatment-related leukemia were also infrequent, though they were numerically higher in the AC arm.

The results of this study clearly do not support use of six-cycle anthracycline-based regimens in node-negative breast cancer. Since this trial completed accrual, management of adjuvant therapy in node-negative breast cancer has substantially evolved. In hormone receptor-positive breast cancer, multigene expression assays such as the Oncotype DX Recurrence Score ${ }^{12,13}$ and the Mammaprint ${ }^{14}$ are used to identify patients who do not benefit from chemotherapy and can receive endocrine therapy alone. When chemotherapy is indicated for hormone receptorpositive, node-negative patients, four cycles of docetaxel and cyclophosphamide (TC) have been demonstrated to be superior to four cycles of AC, providing improved outcomes without exposure to the potential cardiotoxicity of anthracyclines. In hormone receptor-negative, node-negative patients, options include sequential administration of four cycles of $A C$ and a taxane or four cycles of TC, depending on tumor size and grade, patient preference, and comorbidity. Thus, AC alone for four cycles has largely been eliminated as a regimen for node-negative breast cancer.

The statistically significant interaction between treatment and hormone receptor status is noteworthy. In the twothirds of patients with hormone receptor-positive breast cancer, nine-year DFS was numerically lower with FEC-100 (80.8\%) vs. AC (85.0\%), with an HR of 1.32 (95\% Cl 1.05-1.66). In contrast, in the one third of patients with hormone receptor-negative disease, nine-year DFS was higher with FEC-100 (76.5\%) vs. AC (70.9\%), with an HR of 0.86 (95\% Cl 0.66-1.11). Although not conclusive, the data is consistent with a hypothesis that in hormone receptor-positive breast cancers, optimal duration of chemotherapy may be four cycles and that longer regimens, which result in a more extended delay in initiation of endocrine therapy, may be detrimental in some patients with hormone therapy responsive, node-negative breast cancers.

\section{Declarations}

\section{Funding:}

This work was supported by the National Institutes of Health grants U10-CA-180868, -189867

-180822, and -44066-26; and Pharmacia \& Upjohn Company, a subsidiary of Pfizer, Inc.

The authors would also like to acknowledge John Wilson, PhD (retired), who was the original Protocol

Statistician for the study and was an invaluable part of the protocol team.

\section{Acknowledgements:}

The authors would also like to acknowledge John Wilson, PhD (retired), who was the original

Protocol Statistician for the study and was an invaluable part of the protocol team. 
The authors acknowledge the contributions of Barbara C. Good, PhD, Director of Scientific Publications, Christine I. Rudock, Publications and Graphics Specialist, and Wendy L. Rea, BA, Editorial Associate, all of whom are employees of NSABP. They were not compensated beyond their normal salaries for this work.

\section{Authors' Contributions}

1. Conceptualization: CE Geyer, Jr., H Bandos, P Rastogi, L Fehrenbacher, JT Hamm, SM Swain, EP Mamounas, N Wolmark.

2. Methodology: CE Geyer, Jr., H Bandos, SM Swain.

3. Software: H Bandos.

4. Validation: H Bandos, EP Mamounas.

5. Formal Analysis: $\mathrm{H}$ Bandos.

6. Investigation: CE Geyer, Jr., P Rastogi, A Robidoux, L Fehrenbacher, PJ Ward, J Polikoff, AM Brufsky, L Provencher, JT Hamm, L Baez-Diaz, TB Julian, SM Swain, HR Shibata, EP Mamounas, N Wolmark.

7. Resources: A Robidoux, L Fehrenbacher, J Polikoff, AM Brufsky, AHG Paterson, AM Brufsky, L Fehrenbacher, L Provencher, TB Julian, EP Mamounas.

8. Data Curation: H Bandos, A Robidoux.

9a. Writing - Original Draft: CE Geyer, Jr., H Bandos, P Rastogi, SA Jacobs, AM Brufsky, L Provencher, JT Hamm, SM Swain.

9b. Writing - Review \& Editing: CE Geyer, Jr., H Bandos, P Rastogi, L Fehrenbacher, PJ Ward, J Polikoff, AM Brufsky, AHG Paterson, L Provencher, JT Hamm, RL Carolla, TB Julian, SM Swain, EP Mamounas, N Wolmark.

10. Visualization: CE Geyer, Jr., H Bandos, P Rastogi, SM Swain, EP Mamounas.

11. Supervision: CE Geyer, Jr., L Fehrenbacher, L Provencher, EP Mamounas, N Wolmark.

12. Project Administration: CE Geyer, Jr.; N Wolmark.

13. Funding Acquisition: N Wolmark.

Availability of Data and Material (data transparency)

Individual participant data that underlie the results reported in this article, after deidentification, will generally be available within one year after publication and will be accessible through the NCTN Data Archive.

\section{Disclosure of potential conflicts of interest}

Charles E. Geyer, Jr. - Grants, non-financial support and other from Genentech/Roche, Daiichi/Sankyo, and AstraZeneca, during the conduct of the study, and personal fees from Exact Sciences and Athenex, outside the submitted work.

Priya Rastogi: Genentech/Roche - Unpaid advisory boards, travel, accommodations; Lilly - Travel, 
accommodations; Astra/Zeneca - Travel, accommodations.

Johnathan Polikoff - Consultant, Natera.

Louise Provencher: Consulting or Advisory Role: Lilly, Pfizer, Roche, Novartis; Research Funding: Pfizer, Roche, Novartis, Merck, GlaxoSmithKline, Odonate Therapeutics

Sandra M. Swain: Personal Fees for consulting/advisory services/nonpromotional speaking: AstraZeneca, Athenex, Daiichi-Sankyo, Genentech/Roche, Exact Sciences (Genomic Health), Eli Lilly and Company, Bejing Medical Award Association, Merck, Natera, Molecular Templates, Silverback Therapeutics; Non-financial support (i.e., travel, accommodations, and/or food \& beverage); Genentech/Roche: Research support (to institution): Genentech/Roche, Kailos Genetics; Other support: AstraZeneca (member, independent data monitoring committee) and Genentech/Roche (third-party writing assistance).

Eleftherios P. Mamounas:Genentech/Roche, Exact Sciences: Consultant (Advisory Board) and Speaker's Bureau. Biotheranostics, Daiichi Sankyo, Puma Biotechnology, Merck: Consultant (Advisory Board).

\section{Notes}

The funders had no role in the design of the study; the collection, analysis, and/or interpretation of the data; the writing of the manuscript; or the decision to submit the manuscript for publication.

\section{References}

1. Fisher B, Brown AM, Dimitrov NV, et al. Two months of doxorubicin-cyclophosphamide with and without interval reinduction therapy compared with 6 months of cyclophosphamide, methotrexate, and fluorouracil in positive-node breast cancer patients with tamoxifen-nonresponsive tumors: results from the National Surgical Adjuvant Breast and Bowel Project B-15. J Clin Oncol. 1990;8(9):1483-

1496.https://pubmed.ncbi.nlm.nih.gov/2202791/

2. Fisher B, Anderson S, Tan-Chiu E, et al. Tamoxifen and chemotherapy for axillary node-negative, estrogen receptor-negative breast cancer: findings from National Surgical Adjuvant Breast and Bowel Project B-23. J Clin Oncol. 2001 Feb 15;19(4):931-42. doi: 10.1200/JC0.2001.19.4.931. PMID: 11181655.

https://pubmed.ncbi.nlm.nih.gov/11181655/

3. Hutchins LF, Green SJ, Ravdin PM, et al. Randomized, controlled trial of cyclophosphamide, methotrexate, and fluorouracil versus cyclophosphamide, doxorubicin, and fluorouracil with and without tamoxifen for high-risk, node-negative breast cancer: Treatment results of Intergroup Protocol INT-0102. J Clin Oncol. 2005;23(33):8313-8321.https://pubmed.ncbi.nIm.nih.gov/16293862/

4. Levine MN, Pritchard KI, Bramwell VH, et al. Randomized trial comparing cyclophosphamide, epirubicin, and fluorouracil with cyclophosphamide, methotrexate, and fluorouracil in premenopausal women with node- 
positive breast cancer: update of National Cancer Institute of Canada Clinical Trials Group Trial MA5. J Clin Oncol. 2005;23(22):5166-5170.https://pubmed.ncbi.nlm.nih.gov/16051958/Bottom of Form

5. Fumoleau P, Kerbrat P, Romestaing P, et al. Randomized trial comparing six versus three cycles of epirubicinbased adjuvant chemotherapy in premenopausal, node-positive breast cancer patients: 10-year follow-up results of the French Adjuvant Study Group 01 trial. J Clin Oncol. 2003;21(2):298305.https://pubmed.ncbi.nlm.nih.gov/12525522/

6. Bonneterre J, Roché $H$, Kerbrat $P$, et al. Epirubicin increases long-term survival in adjuvant chemotherapy of patients with poor-prognosis, node-positive, early breast cancer: 10-year follow up results of the French Adjuvant Study Group 05 randomized trial. J Clin Oncol. 2005;23(12):2686-2693. https://pubmed.ncbi.nlm.nih.gov/15837983/

7. White SJ, Freedman LS. Allocation of patients to treatment groups in a controlled clinical study. Br J Cancer 37: 849-857, 1978. https://pubmed.ncbi.nlm.nih.gov/350254/

8. Ganz PA, Bandos H, Robidoux A, et al. Behavioral and health outcomes from the NRG Oncology/NSABP B-36 trial comparing two different adjuvant therapy regimens for early-stage node-negative breast cancer.

\section{(Companion submission).}

9. Lin DY, Wei LJ, Ying Z. Checking the Cox model with cumulative sums of martingale-based residuals. Biometrika; 80: 557-572, 1993. https://www.jstor.org/stable/2337177?seq=1

10. Jacobs SA, Wilson JW, Bandos H, et al. NSABP B-36: A randomized phase III trial comparing six cycles of 5fluorouracil (5-FU), epirubicin, and cyclophosphamide (FEC) to four cycles of adriamycin and cyclophosphamide (AC) in patients (pts) with node-negative breast cancer. Cancer Res 75 (9 Suppl); SABCS 2014 December 9-13, 2015; San Antonio, TX. Abstr S3-02. https://cancerres.aacrjournals.org/content/75/9_Supplement/S3-02

11. McNeil C. Consensus panel endorses range of adjuvant therapies for breast cancer. J Natl Cancer Inst. 2000 Dec 6;92(23):1870. doi: 10.1093/jnci/92.23.1870. PMID: 11106671.

https://academic.oup.com/jncimono/article/2001/30/5/936243?searchresult=1

12. Paik S, Tang G, Shak S, et al. Gene expression and benefit of chemotherapy in women with node-negative, estrogen receptor-positive breast cancer. J Clin Oncol; 24:3726-3734, 2006.

https://pubmed.ncbi.nlm.nih.gov/16720680/

13. Sparano JA, Gray RJ, Makower DF, et al. Adjuvant chemotherapy guided by a 21-Gene Expression Assay in breast cancer. N Engl J Med; 379:111-121, 2018. https://pubmed.ncbi.nlm.nih.gov/29860917/

14. Cardoso F, van't Veer LJ, Bogaerts J; MINDACT Investigators. 70-Gene Signature as an aid to treatment decisions in early-stage breast cancer. N Engl J Med; 375:717-29, 2016.

https://pubmed.ncbi.nlm.nih.gov/27557300/

\section{Figures}




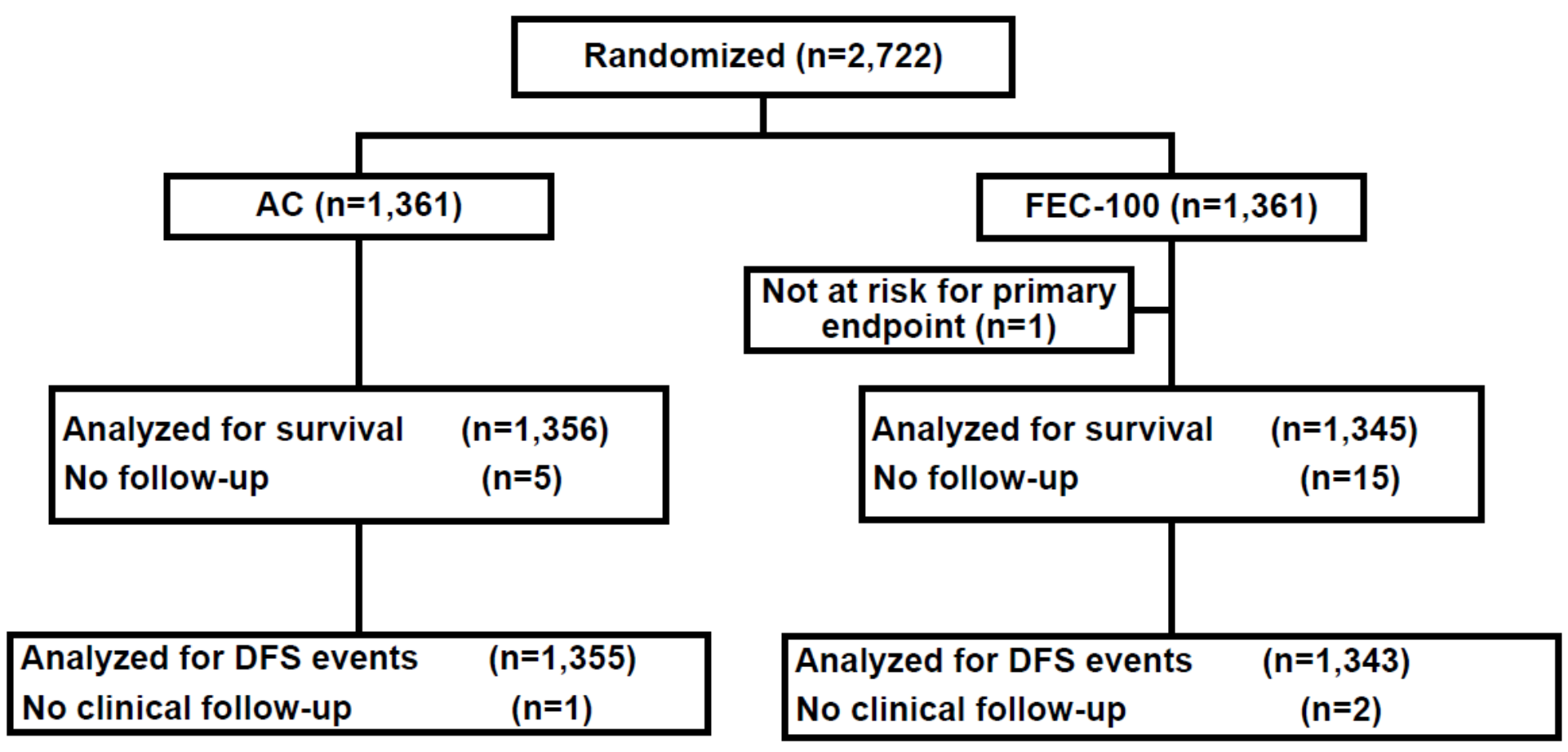

Figure 1

CONSORT diagram. AC=doxorubicin and cyclophosphamide; FEC-100=5-fluorouracil, epirubicin and cyclophosphamide. 

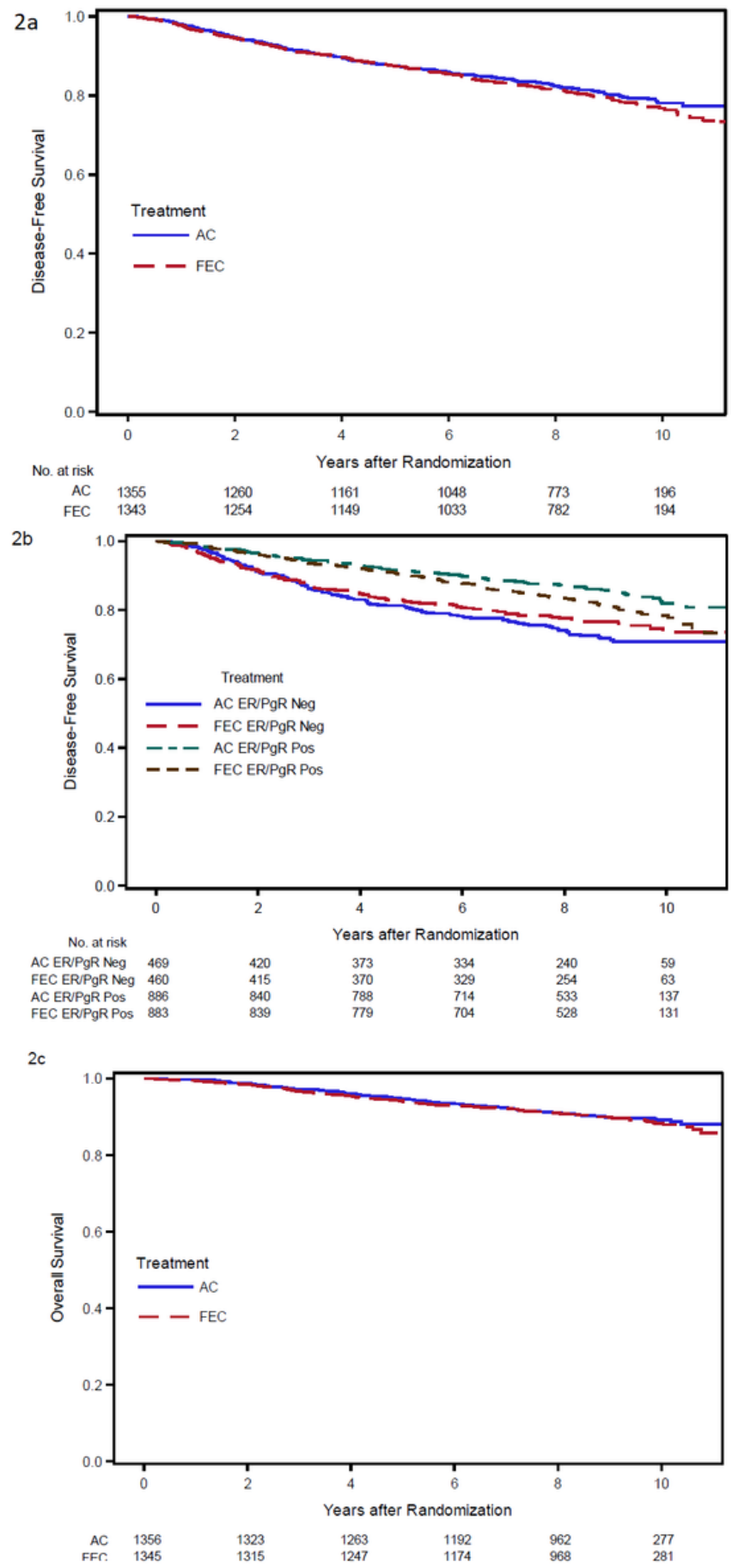

Figure 2

2a. Kaplan-Meier estimates of disease-free survival. AC=doxorubicin and cyclophosphamide; FEC-100=5fluorouracil, epirubicin and cyclophosphamide. 2b. Kaplan-Meier estimates of disease-free survival by treatment and receptor status. AC=doxorubicin and cyclophosphamide; ER=estrogen receptor; FEC-100=5-fluorouracil, epirubicin and cyclophosphamide; PgR=progesterone receptor. 2c. Kaplan-Meier estimates of overall survival. $\mathrm{AC}=$ doxorubicin and cyclophosphamide; FEC-100=5-fluorouracil, epirubicin and cyclophosphamide

\section{Supplementary Files}

This is a list of supplementary files associated with this preprint. Click to download. 
- B36TablesSuppl20200831.docx

- B36FiguresSuppl20200831.pdf 